\title{
SYNOVIAL MEMBRANE IN TRAUMATIC EFFUSION
}

\section{ULTRASTRUCTURE AND AUTORADIOGRAPHY WITH TRITIATED LEUCINE}

BY

\author{
S. ROY, F. N. GHADIALLY, AND W. A. J. CRANE \\ Department of Pathology, University of Sheffield
}

Of the two main constituents of synovial fluid, hyaluronic acid is probably formed by the synovial membrane (Yielding, Tomkins, and Bunim, 1957; Hedburg and Moritz, 1958) and most of the proteins are believed to come from plasma (Hamerman, Sandson, and Schubert, 1963; Curtiss, 1964). Normal synovial cells apparently play no part in protein synthesis (Hamerman and Schubert, 1962). In traumatic effusion, the protein concentration of synovial fluid is increased (Ropes and Bauer, 1953; Decker, McKenzie, McGuckin, and Slocumb, 1959; Binette and Schmid, 1965), but it is not known whether some of this excess protein is formed by the synovial cells.

The present study was undertaken to determine the protein synthetic potential of normal and pathological synovial membrane in man, using the electron microscope and histochemical and autoradiographic techniques. The results from synovial biopsies in traumatic joint effusion indicate an increased capacity for protein synthesis by synovial cells in these circumstances.

\section{Material and Methods}

22 samples of human synovial membrane were studied. Four were collected from cases without any joint disease: two came from the knee joint of patients requiring midthigh amputation for gangrene of the foot, one from the ankle during the correction of club foot, and one from the elbow of a patient undergoing amputation for sarcoma of the scapula. The remaining eighteen samples were obtained from the knee joint of patients with torn menisci during meniscectomy. At operation most joints contained a traumatic effusion. Its volume was estimated, and according to the amount present the cases were divided into four groups:

$$
\begin{array}{lll}
\text { I. No effusion } & \text { III. } & 5-10 \mathrm{ml} \\
\text { II. }<5 \mathrm{ml} . & \text { IV. } & >10 \mathrm{ml} \text {. }
\end{array}
$$

All the samples of synovial membrane were collected from the parapatellar region, and each was divided into two parts for electron microscopy and autoradiography. One part (about $4 \mathrm{sq}$. $\mathrm{mm}$.) was placed on filter paper and dropped into buffered osmium (Palade, 1952). After fixation for $2 \mathrm{hrs}$ the tissue was removed from the filter paper and cut into strips approximately $1 \mathrm{~mm}$. wide. These were orientated according to the method of Coulter (1962) and processed and embedded in araldite (Glauert, 1961). Ultra-thin sections were cut with a Huxley or Porter Blum microtome, mounted on uncoated copper grids, stained with lead citrate (Reynolds, 1963), and examined with an A.E.I. EM6 using an accelerating voltage of 50 or $75 \mathrm{kV}$.

The other part (about $6 \times 2 \mathrm{~mm}$.) was placed in $5 \mathrm{ml}$. of Krebs's buffer solution containing ${ }^{3} \mathrm{H}$-leucine (Lleucine-4,5-T obtained from the Radiochemical Centre, Amersham) at a concentration of $5 \mu \mathrm{c}$. $/ \mathrm{ml}$. This was incubated at $37^{\circ} \mathrm{C}$. for 1 to $2 \mathrm{hrs}$. The tissue was then fixed in 10 per cent. neutral formalin and processed to paraffin. Autoradiographs were prepared from $5 \mu$ sections with fine-grain film stripped from Kodak AR 10 plates. They were exposed at $4^{\circ} \mathrm{C}$. in dry air for 4 to 6 wks. In some cases a control sample of synovial membrane was either boiled for 2 to 3 min., kept at room temperature for 2 to $8 \mathrm{hrs}$, or incubated with potassium cyanide $(\mathrm{KCN})$ at a concentration of $10^{-1}$ mole per litre for 1 to $4 \mathrm{hrs}$ before incubating with ${ }^{3} \mathrm{H}$-leucine and preparing autoradiographs. After exposure the autoradiographs were developed with Kodak D 19B, fixed, and stained through the film with 1 per cent. aqueous neutral red. Serial sections from the same paraffin block were stained with haematoxylin and eosin, with methyl green-pyronin for RNA, and with a variety of stains for acid mucopolysaccharides, including alcian blue, toluidine blue, and McManus and Mowry's modification of Hale's colloidal iron stain (1960).

Sections stained for RNA from nineteen cases were examined in detail by light microscopy. Consecutive synovial cells from the superficial layer of the membrane were counted and divided into four grades. The first (Grade 0) comprised cells that showed no distinctive RNA staining of the cytoplasm; the remainder were subdivided according to a cytoplasmic RNA reaction of increasing intensity (Grades,,++++++ ). 


\section{Light Microscopy}

\section{Results}

The synovial membrane from patients with traumatic effusion showed an occasional small focus of proliferation of synovial cells and some mild lymphocytic infiltration of the sub-synovial tissue, but otherwise there was no significant variation from the normal with routine stains.

The results of methyl green-pyronin staining for RNA are shown in the Table and in Fig. 1.

TABLE

RNA STAINING OF SYNOVIAL CELLS FROM NORMAL AND TRAUMATIZED HUMAN JOINTS

\begin{tabular}{|c|c|c|c|c|c|}
\hline \multirow{2}{*}{ Group } & \multirow{2}{*}{$\begin{array}{c}\text { Volume of } \\
\text { Synovial } \\
\text { Effusion (ml.) }\end{array}$} & \multicolumn{4}{|c|}{ Grades of RNA Staining } \\
\hline & & 0 & + & ++ & +++ \\
\hline Normal & - & $\begin{array}{l}69 \cdot 4 \\
54 \cdot 7 \\
81 \cdot 0\end{array}$ & $\begin{array}{l}27 \cdot 5 \\
41 \cdot 2 \\
19 \cdot 0\end{array}$ & $\begin{array}{l}3 \cdot 1 \\
4 \cdot 1 \\
0\end{array}$ & $\begin{array}{l}\mathbf{0} \\
\mathbf{0} \\
\mathbf{0}\end{array}$ \\
\hline I & 0 & $\begin{array}{l}45 \cdot 2 \\
51 \cdot 1 \\
42 \cdot 7 \\
80 \cdot 4\end{array}$ & $\begin{array}{l}49 \cdot 8 \\
37 \cdot 2 \\
42 \cdot 3 \\
18 \cdot 8\end{array}$ & $\begin{array}{r}5 \cdot 0 \\
8 \cdot 1 \\
11 \cdot 6 \\
0.8\end{array}$ & $\begin{array}{l}0 \\
3 \cdot 6 \\
3 \cdot 4 \\
0\end{array}$ \\
\hline II & $1-5$ & $\begin{array}{l}45 \cdot 9 \\
24 \cdot 3 \\
29 \cdot 0 \\
53 \cdot 3\end{array}$ & $\begin{array}{l}40 \cdot 5 \\
60 \cdot 0 \\
58 \cdot 6 \\
38 \cdot 4\end{array}$ & $\begin{array}{r}10 \cdot 2 \\
13 \cdot 4 \\
9 \cdot 8 \\
7 \cdot 5\end{array}$ & $\begin{array}{l}3 \cdot 4 \\
2 \cdot 3 \\
2 \cdot 6 \\
0 \cdot 8\end{array}$ \\
\hline III & $5-10$ & $\begin{array}{l}14 \cdot 0 \\
16 \cdot 3 \\
29 \cdot 4 \\
24 \cdot 8\end{array}$ & $\begin{array}{l}37 \cdot 6 \\
38 \cdot 4 \\
43 \cdot 3 \\
53 \cdot 2\end{array}$ & $\begin{array}{l}21 \cdot 4 \\
21 \cdot 0 \\
16 \cdot 0 \\
14 \cdot 0\end{array}$ & $\begin{array}{r}27 \cdot 0 \\
24 \cdot 3 \\
11 \cdot 3 \\
8 \cdot 0\end{array}$ \\
\hline IV & $>10$ & $\begin{array}{r}11 \cdot 2 \\
4 \cdot 3 \\
2 \cdot 7 \\
7 \cdot 4\end{array}$ & $\begin{array}{l}11 \cdot 6 \\
14 \cdot 9 \\
47 \cdot 7 \\
50 \cdot 8\end{array}$ & $\begin{array}{l}13 \cdot 6 \\
13 \cdot 4 \\
30 \cdot 9 \\
29 \cdot 6\end{array}$ & $\begin{array}{l}63 \cdot 6 \\
67 \cdot 4 \\
18 \cdot 7 \\
12 \cdot 2\end{array}$ \\
\hline
\end{tabular}

When the fluid volume was correlated with each RNA grade, correlation coefficients of $-0.894,+0.085,+0.821$, and +0.999
were obtained for the " $0 "$ ", + ", " ++ ," and " $+++"$ grades were obtained for the " $0 "$ " " $+", "++"$, and " +++ " grades
respectively. The first and the last two coefficients were highly significant in showing an increase in RNA-positive cell counts with the increased volume of joint fluid.
Most of the surface cells were either negative (Grade 0 ) or faintly positive (Grade + ) in specimens of normal synovial membrane (Fig. 2, opposite), and meniscectomy cases without effusion (Group I). The numbers of positive cells and the intensity of their reaction was increased in cases with effusion (Grades,+++++ ). Pre-treatment of sections with RNA-ase eliminated the staining reaction (Figs 3 and 4, opposite).

\section{Autoradiography}

The synovial cells, both from normal and traumatic cases, showed intense labelling by ${ }^{3} \mathrm{H}$-leucine (Fig. 5, overleaf).

Because of the intensity of the autoradiographic image it was difficult to appreciate any significant difference in uptake between the normal and the different groups of cases with effusion, and grain counts were not attempted. Fibroblasts and the endothelial cells of the capillaries in the superficial sub-synovial tissue also showed heavy uptake of the isotope. In all of these cell types the autoradiographic reaction was localized over the cytoplasm and the immediate confines of the cell; grains were also present over the nucleus. Collagen fibres in the sub-synovium showed little labelling that was appreciably above background levels. Smooth muscle cells in the media of small arteries in the synovium showed a moderate degree of uptake and the endothelial cells lining their lumen were less intensely labelled than capillary endothelium.

Labelling of the cells in the synovial layer and subsynovial tissues was almost completely inhibited by boiling the sample before incubation (Fig. 6, overleaf) and partly inhibited by storage at room temperature and by cyanide.

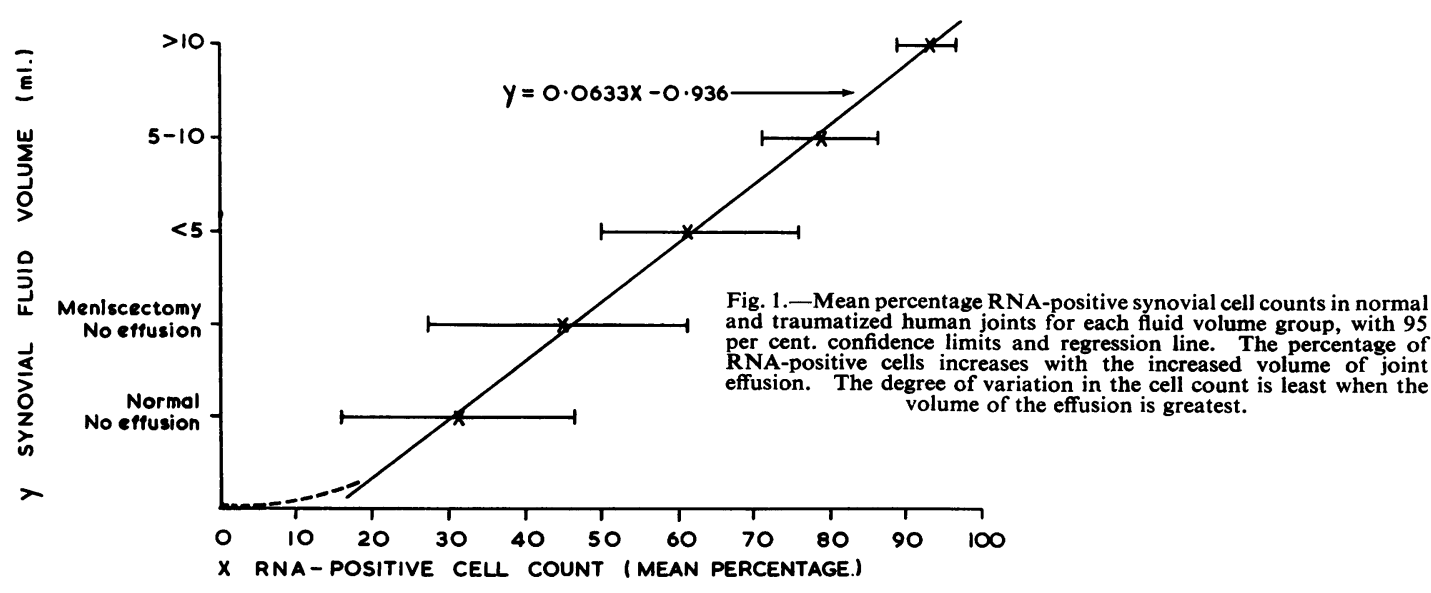


Fig. 2.-Normal synovial membrane. The synovial cells are very faintly positive for RNA. Methyl green-pyronin $\times \mathbf{4 0 0}$.
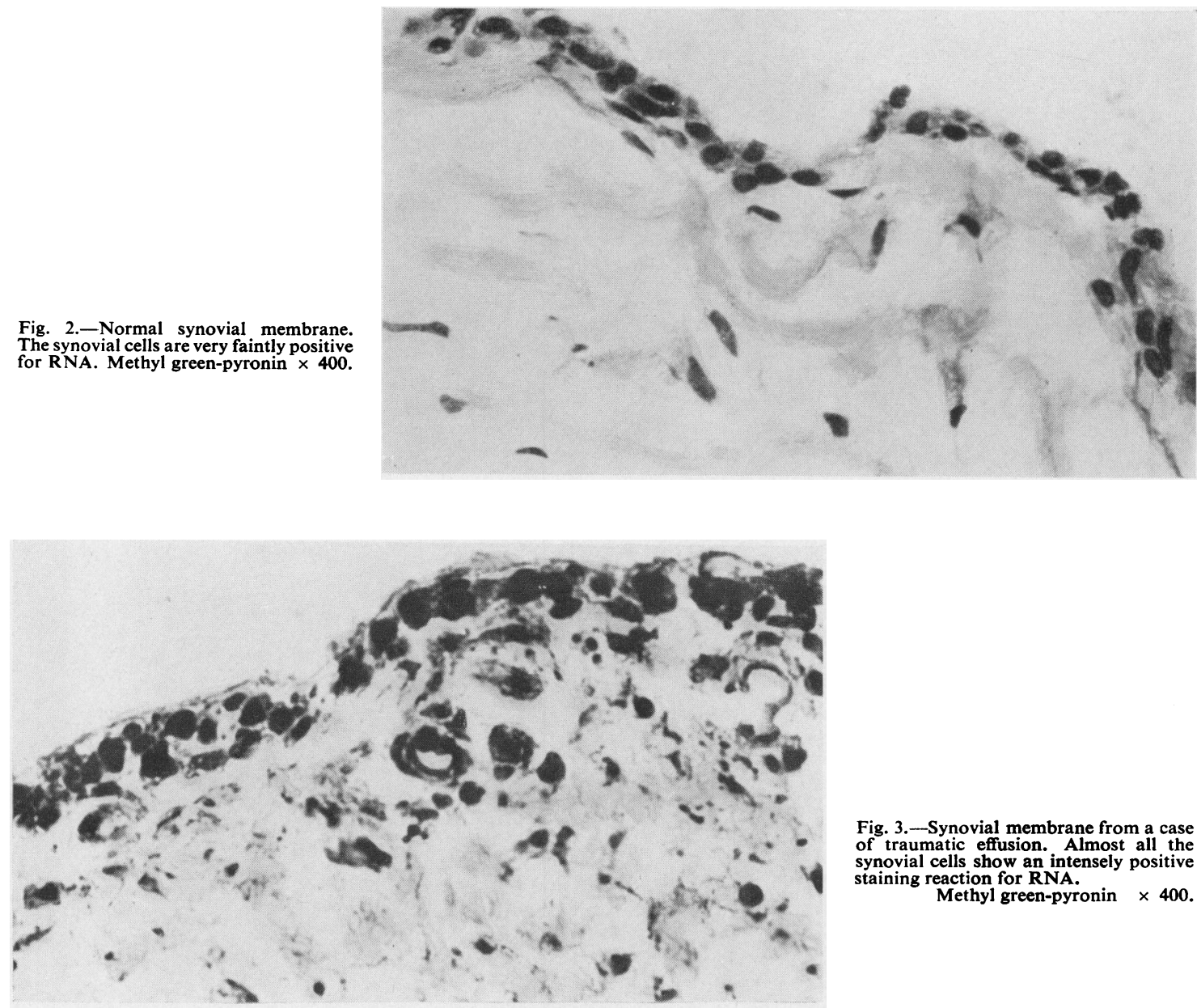

Fig. 3.-Synovial membrane from a case of traumatic effusion. Almost all the synovial cells show an intensely positive staining reaction for RNA. Methyl green-pyronin $\times 400$.

Fig. 4.-Serial section from same block as Fig. 3 stained with methyl green-pyronin after digestion with ribonuclease. The RNA reaction is abolished. $\times 400$.

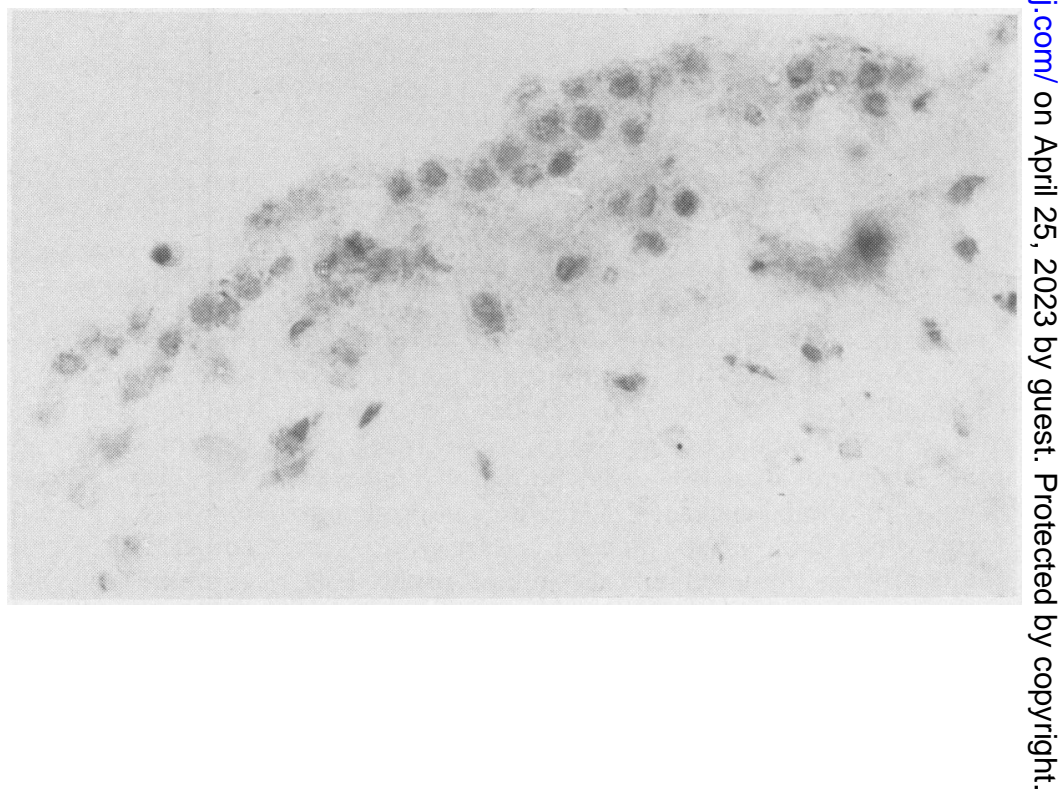




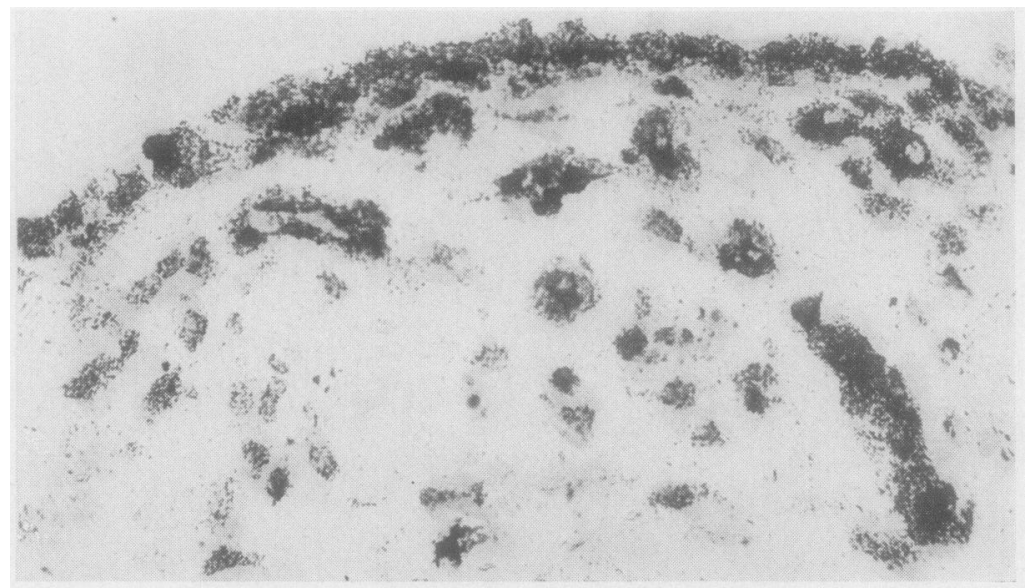

Fig. 5.-Autoradiograph of synovial membrane in traumatic effusion after incubation with ${ }^{3} \mathrm{H}$-leucine in vitro. Note intense radioactive labelling of the surface synovial cells. Capillary endothelium and fibroblasts of the sub-synovial tissues also show marked labelling.

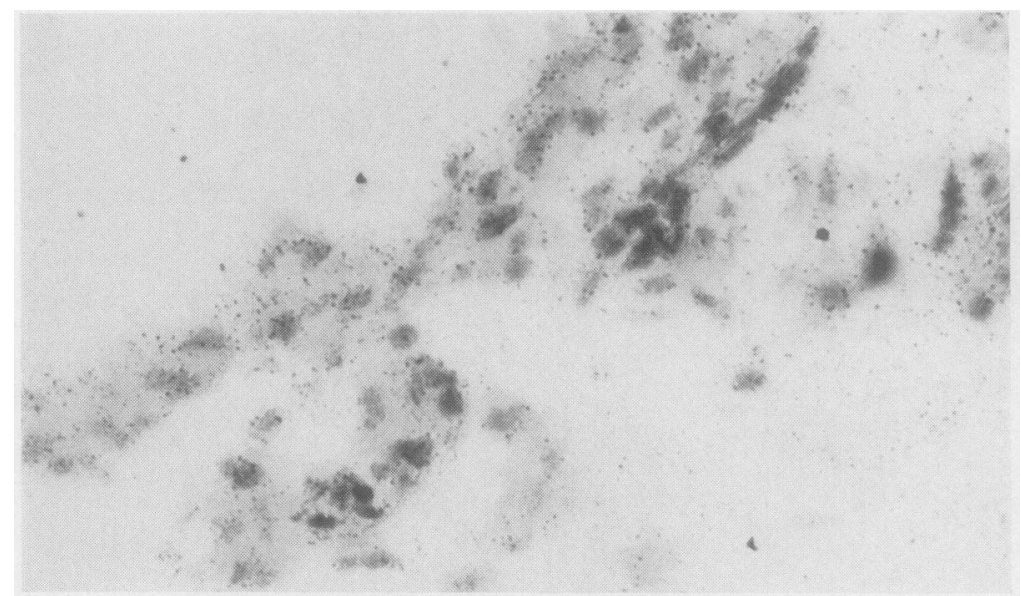

Fig. 6.-Autoradiograph of same case as in Fig. 13. The tissue was boiled before exposure to ${ }^{3} \mathrm{H}$-leucine. Note labelling of the cells is

\section{Electron Microscopy}

Normal Synovial Membrane.-Our findings are somewhat similar to those of Barland, Novikoff, and Hamerman (1962), in that broadly speaking two main types of cell can be found in the normal synovial membrane (Fig. 7, opposite). One variety (Barland, Type A), shows a well-developed Golgi and smooth endoplasmic reticulum (E.R.), while the other (Barland, Type B) shows abundant rough E.R. often with dilated cisternae. However intermediate forms which could not be placed in either group were frequently encountered and abundant rough E.R. and elaborate Golgi systems were often found in the same cell (Fig. 8, overleaf). In our normal material Type A cells were seen much more frequently than ${ }^{\mathrm{N}}$ Type B, as reported by Barland and others (1962). N

Synovial Membrane in Traumatic Effusion._- $-\omega$ Ultrastructural studies of the synovial membrane from traumatic cases, especially when joint effusion was marked, showed that the distinction between Type A and B cells was almost completely lost. The majority of the cells contained large amounts of $\frac{0}{0}$ rough E.R. with dilated cisternae and also had $\stackrel{\mathbb{D}}{\circ}$ complex Golgi systems (Figs 9 and 10, overleaf). 


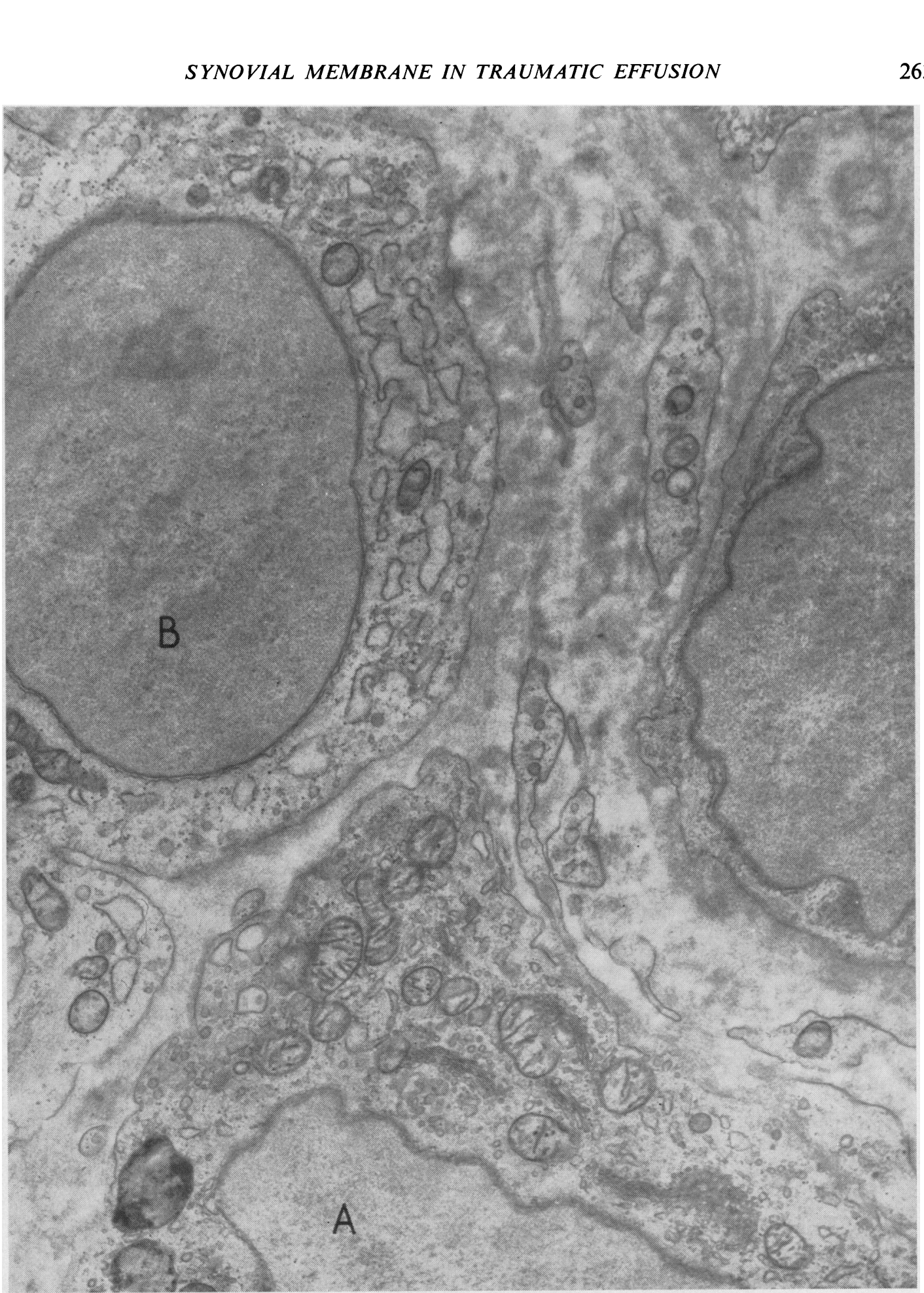

Fig. 7.-Ultrastructure of normal synovial membrane, showing Type

$A$ and $B$ cells.

$\times 15,000$.

$263 \stackrel{\frac{7}{3}}{\stackrel{2}{\vec{D}}}$ 


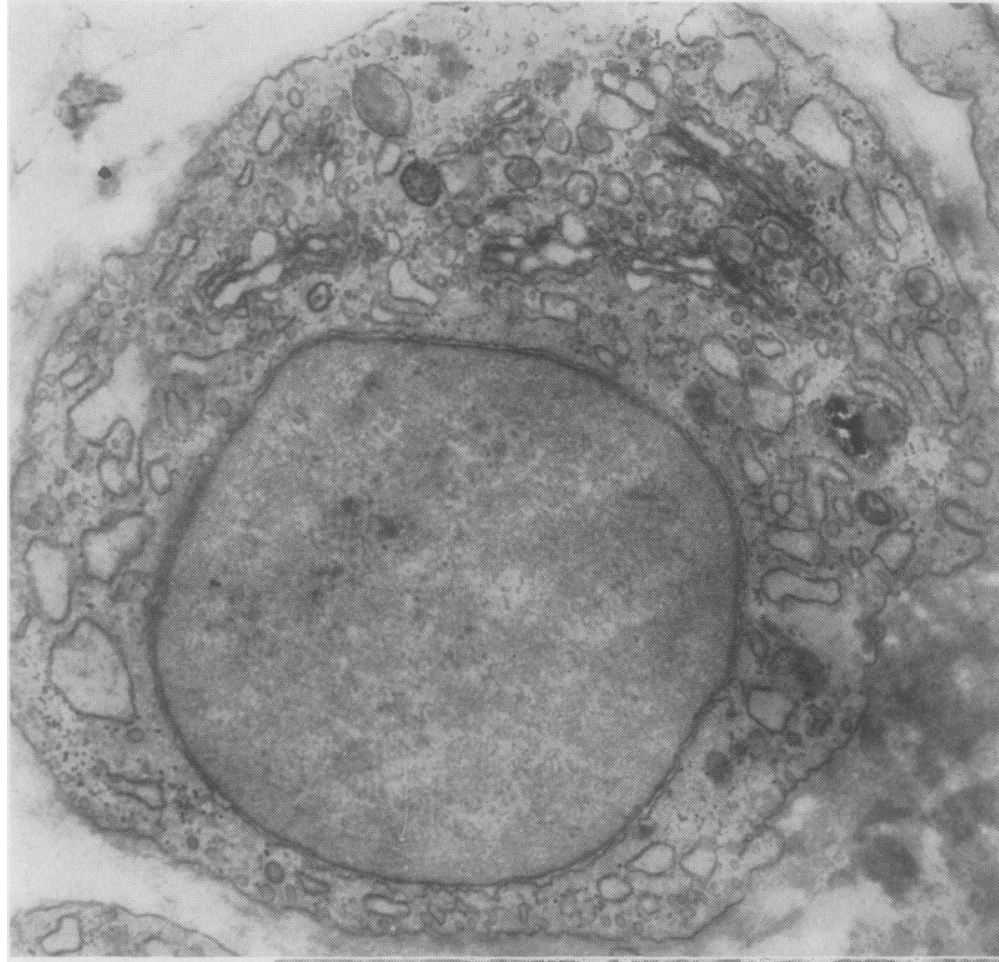

Fig. 8.-Normal synovial cell showing both prominent Golgi systems and abundant rough E.R. (intermediate $\overrightarrow{\boldsymbol{\omega}}$ type).

.

Fig. 9.-Ultrastructure of synovial membrane from traumatic effusion showing an increase

in amount of rough
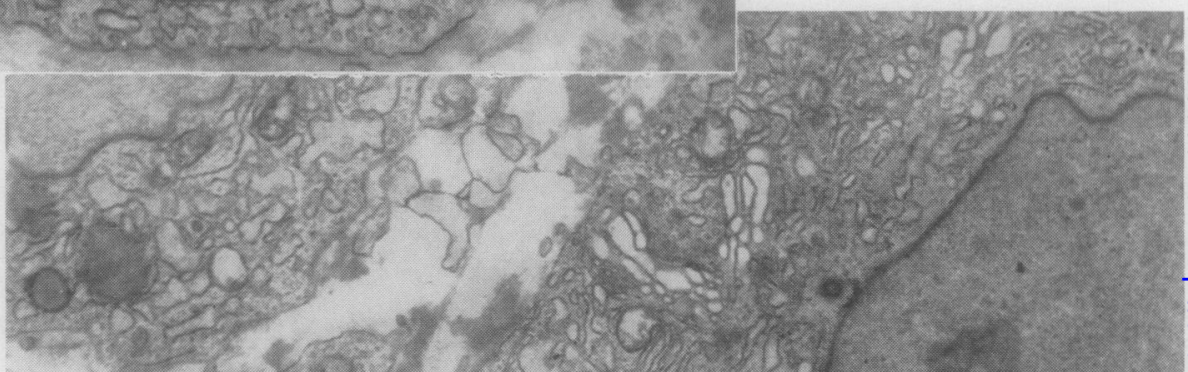

.
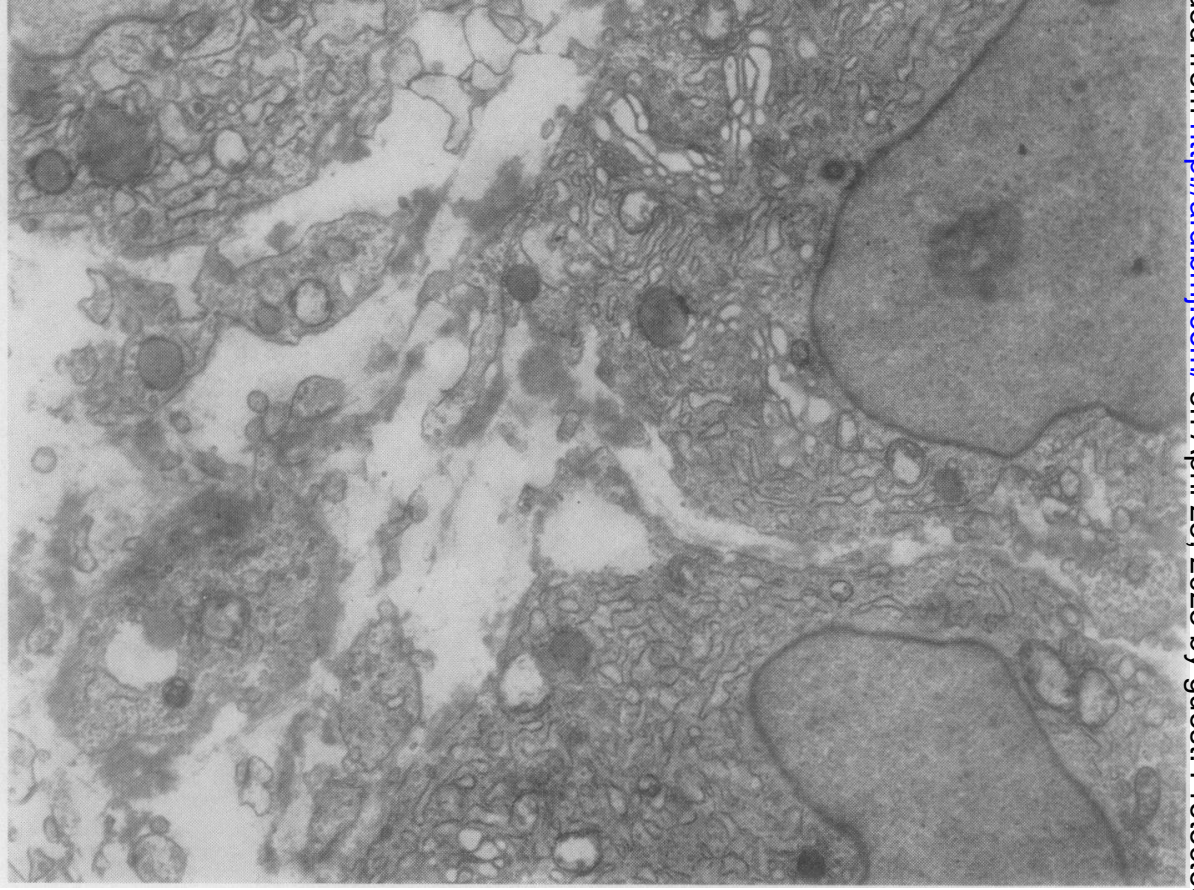


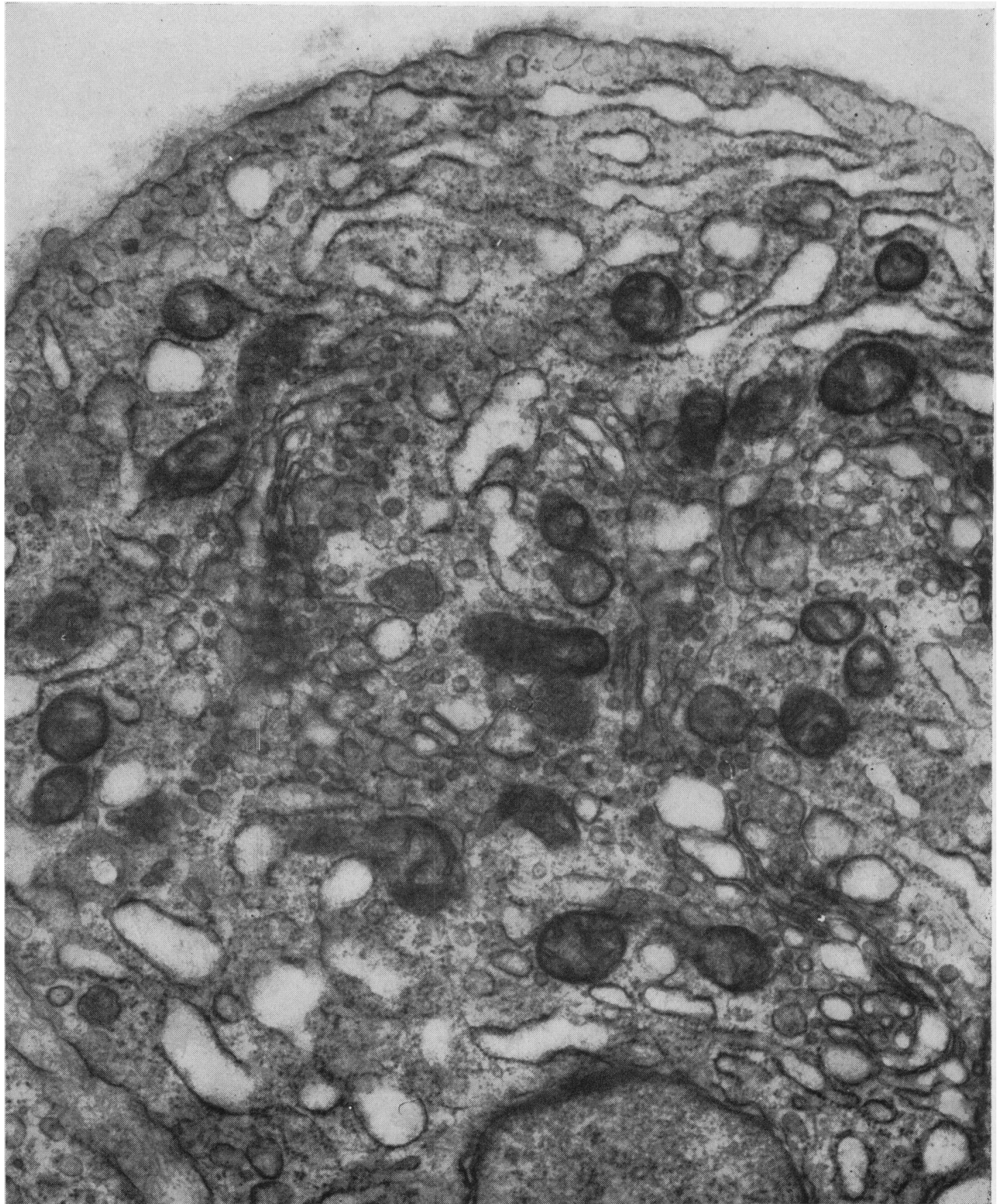

Fig. 10.-Synovial cell from traumatic effusion. Elaborate Golgi systems and abundant rough E.R. are seen in the same cell. 
Of the remaining cells the majority contained large amounts of rough E.R. (Type B) (Fig. 11), while only

an occasional cell with abundant Golgi systems and smooth E.R. could be detected (Type A). The $\frac{\mathrm{T}}{\omega}$.

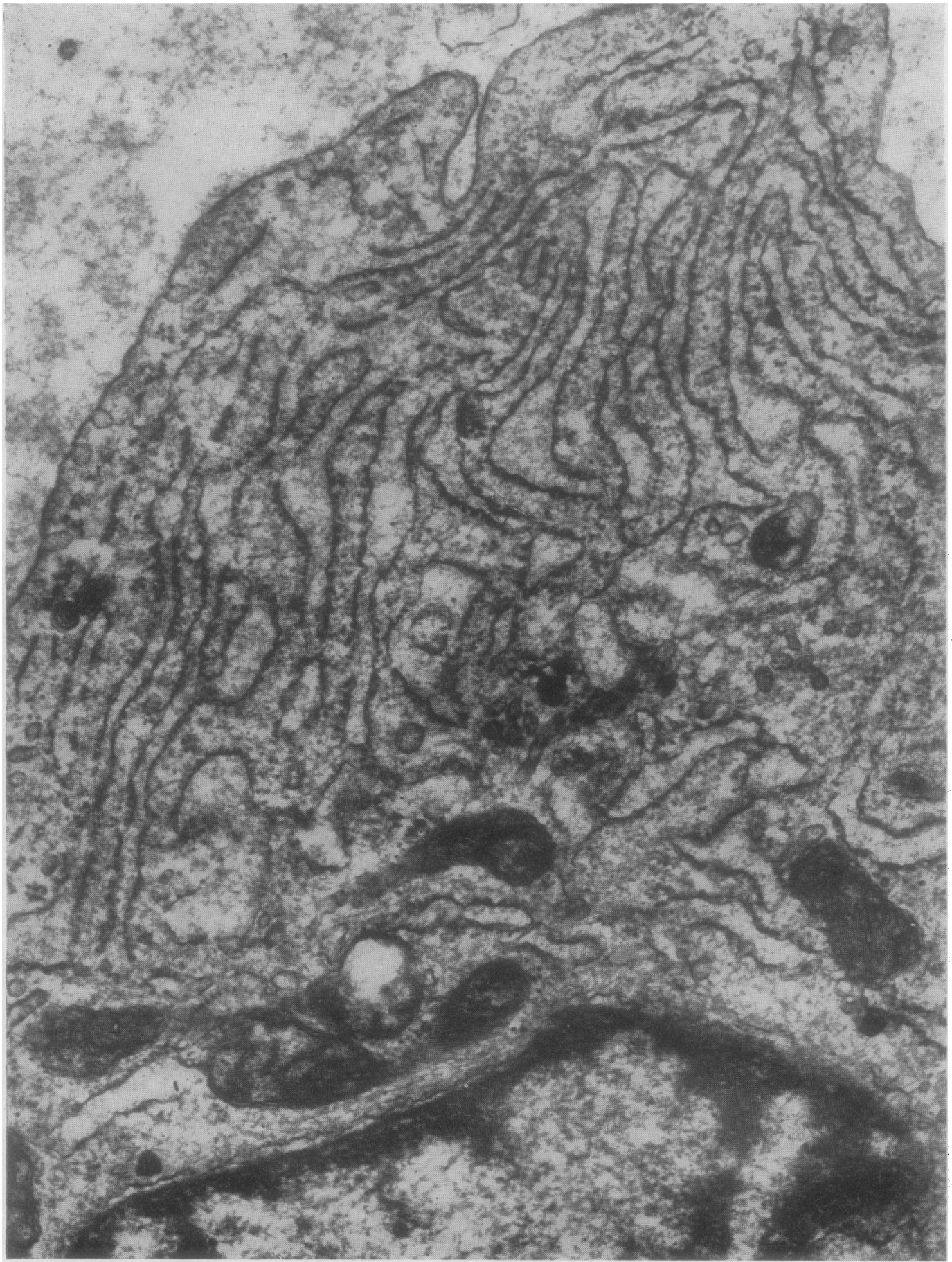

Fig. 11.-Synovial cell from traumatic effusion, showing a marked hyperplasia of the rough E.R.

$\times 40,000$. 
general impression was one of marked hyperplasia of the rough E.R. system. Furthermore, many free ribonucleoprotein particles were also scattered throughout the cytoplasm (Fig. 12). It is our impression that the amount of rough E.R. was roughly proportional to the amount of fluid present in the joint. Lysosomes were also seen more frequently in effusion cases than in normal cases (Fig. 13, overleaf).

At times large numbers of lysosomes were present in a single cell (Fig. 14, overleaf), a phenomenon not observed by us in normal cases. Occasionally membranous structures were found to be incorporated in a lysosome (Fig. 15, overleaf), indicating that these had arisen from areas of focal cytoplasmic degeneration (Parry and Ghadially, 1965). In two cases with pronounced effusion (Group IV), some lipid droplets were also detected (Fig. 12). We have not seen lipid droplets in normal synovial cells of man.

\section{Discussion}

言

Normal Synovial Membrane.-Hyaluronate and $\frac{}{\bar{F}}$ protein are two important constituents of synovial $\frac{\mathcal{S}}{\vec{D}}$ fluid. It is believed that the former is produced by $\stackrel{\mathbb{Q}}{\Omega}$ the synovial cells (Yielding and others, 1957; \& Hedberg and Moritz, 1958), but whether these cells $\vec{\circ}$ also contribute to the protein content is not known. Shaw and Martin (1962) investigated normal synovial $\vec{\omega}$ membrane and observed a weak positive reaction for RNA in some of its cells. In the present study of normal synovium, the cells were either RNA negative in or weakly positive and the reaction was abolished $\underset{\omega}{\mathcal{N}}$ with RNA-ase.

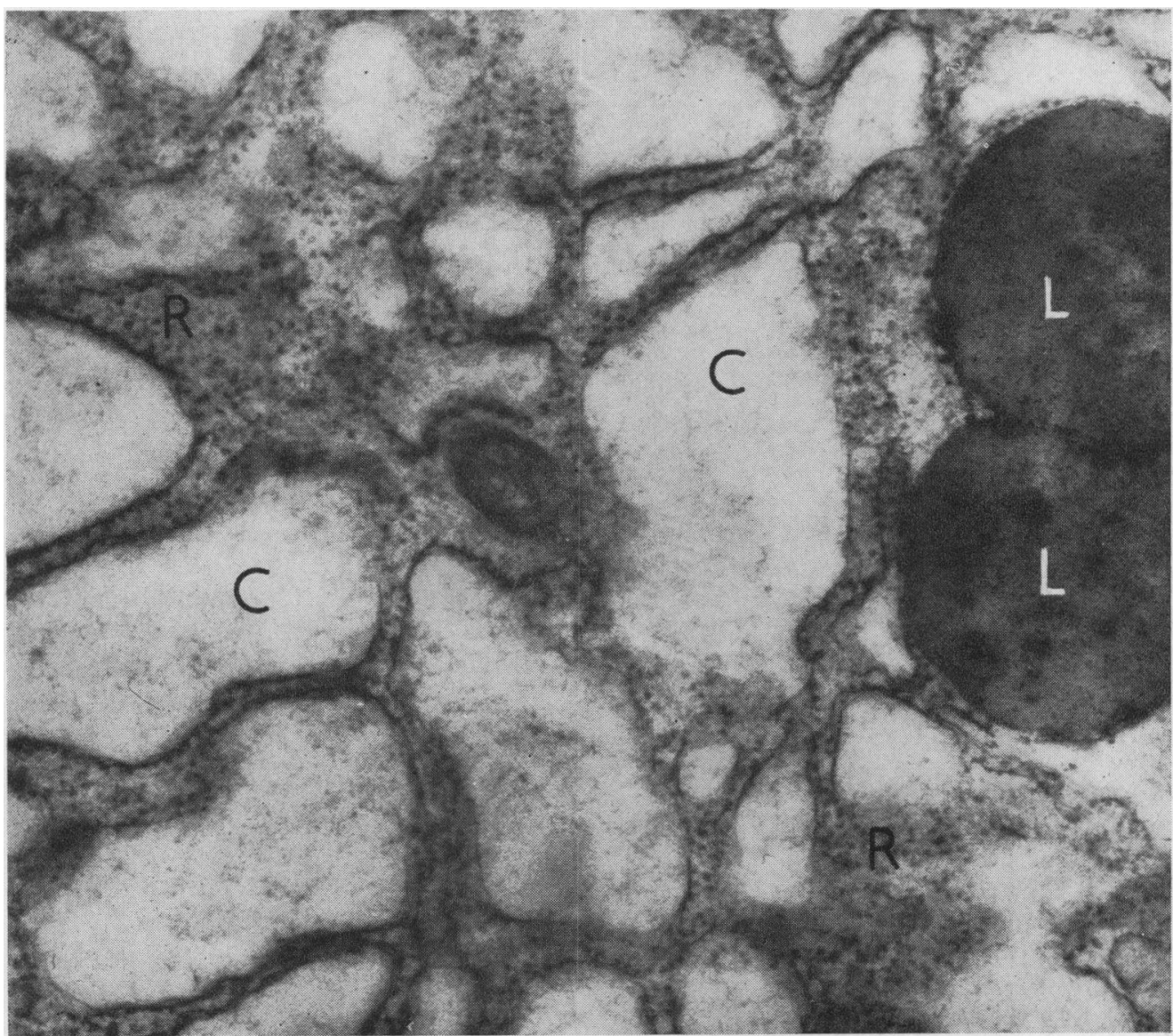

Fig. 12.-Synovial cell from traumatic effusion. Large number of free ribosomes (R) and two lipid droplets (L) are seen. The cisternae
(C) of the rough E.R. are dilated. 


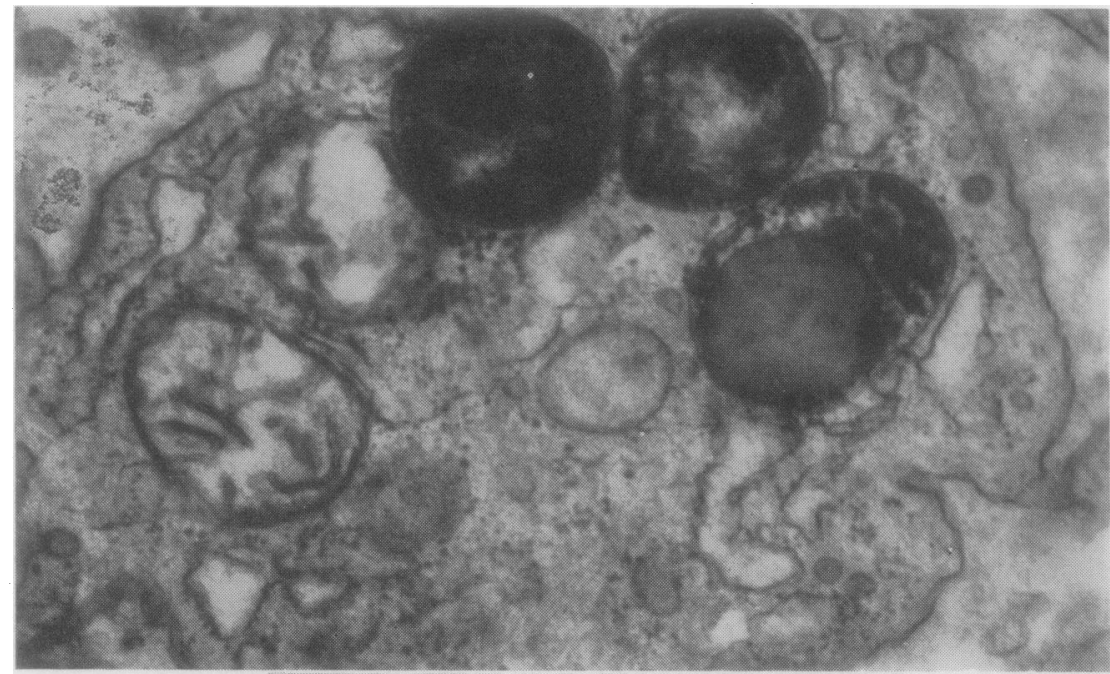

Fig, 13,-Synovial cell from traumatic effusion, showing three $\vec{O}$ lysosomes. $\times 34,000$ :

Fig. 14.-Synovial cell from traumatic effusion. Large number of lysosomes are present in a single cell. $\times 32,000$.

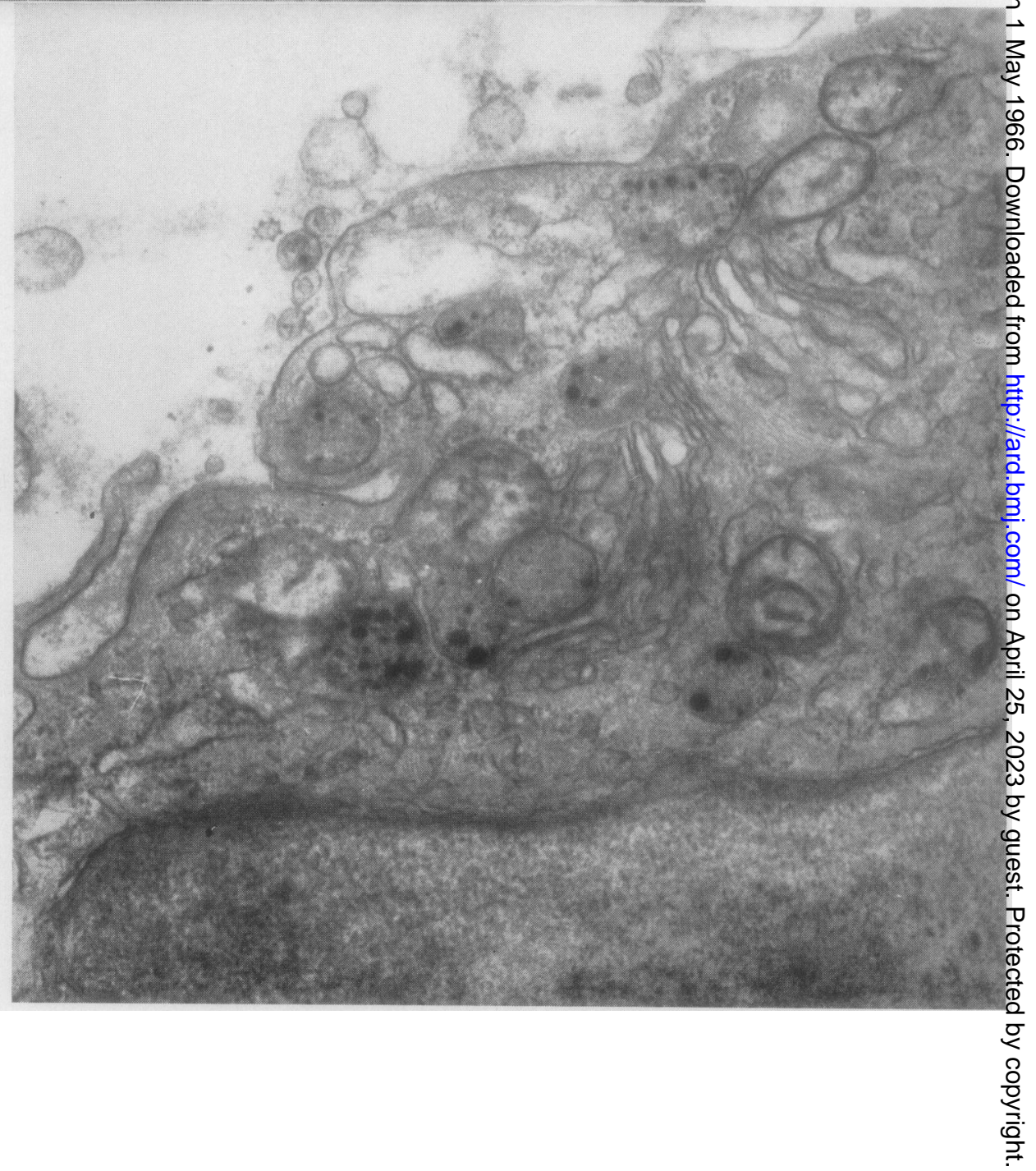




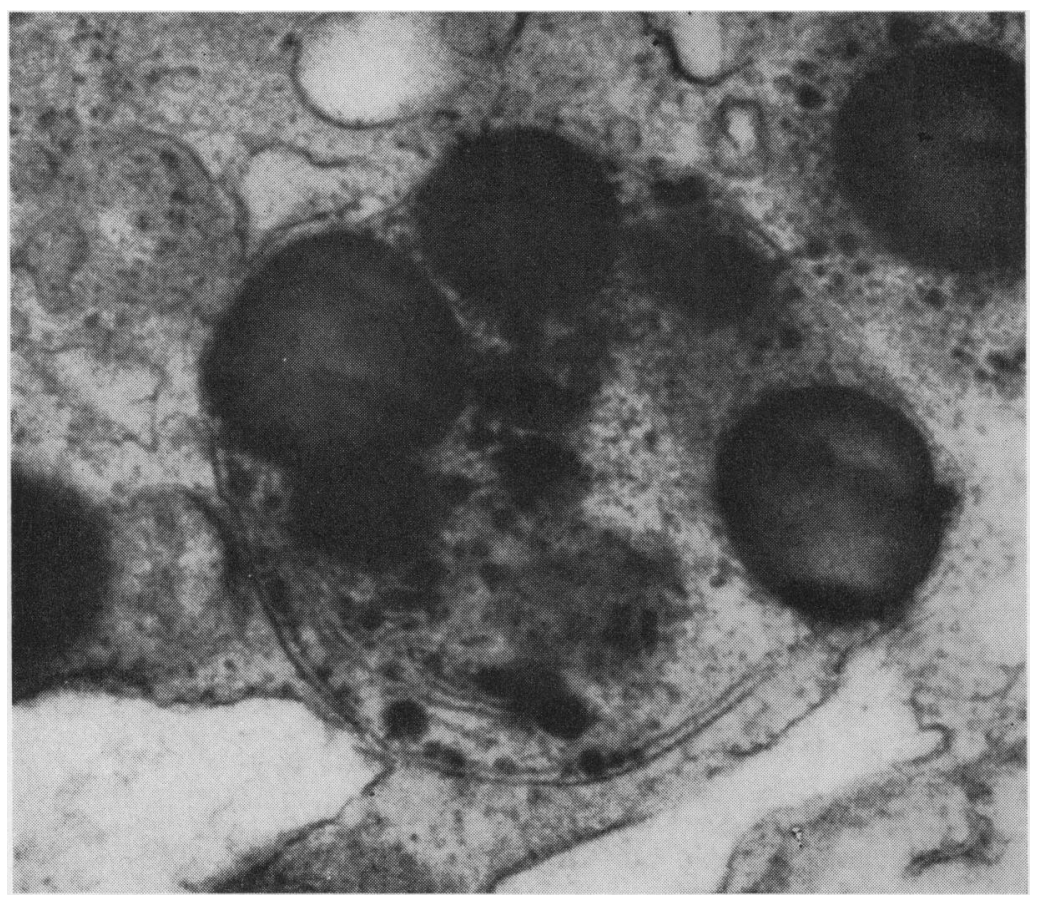

Several reports on the ultrastructural appearance of normal synovial cells have appeared in the literature in recent years (Lever and Ford, 1958; Coulter, 1962; Langer and Huth, 1960; Barland and others, 1962). Barland and others (1962) described two distinct types of cells in man. Type A cells contain many filopodia, large vacuoles, mitochondria, and prominent Golgi apparatus, but very scanty rough E.R. and Palade granules. Type B cells, on the other hand, contain a well-developed rough E.R. and numerous Palade granules, but only a few mitochondria and a poorly-developed Golgi system. These authors considered that Type B cells were less numerous than Type A cells in normal synovium. Our observations with the electron microscope, although similar to those of Barland and others, showed in addition intermediate cells with features common to both types. The more common Type A cell showed a prominent Golgi apparatus and only some had large numbers of mitochondria but vacuoles and filopodia were seen rather infrequently. Type B cells containing a well-developed rough E.R. were less frequent. However, many cells with features of both types were also seen. The presence of a prominent Golgi or rough E.R. appears to us to be a more important criterion for determining cell type than the number of mitochondria or filopodia. The Golgi region in other cells is believed to be the site of mucopolysaccharide synthesis (Peterson and Leblond, 1964), while it is well known that a rough E.R. and Palade granules indicate active protein synthesis (Palade, 1961). It may be that, in the normal synovium, Type A cells which contain a prominent Golgi produce the bulk of the hyaluronic acid while the more scanty Type B cells synthesize some protein. However, the latter function appears to be less important, for most of the protein in normal synovial fluid is thought to be derived from the plasma (Hamerman and others, 1963; Curtiss, 1964). However, since intermediate forms containing both abundant rough E.R. and Golgi are often seen, it would appear that both these cell types are merely functional variants and that the synthesis of both hyaluronic acid and protein can proceed in the same cell. Furthermore, our autoradiographic studies with ${ }^{3} \mathrm{H}$-leucine indicate the marked uptake of the radioactive amino acid which occurs in normal synovial cells in vitro. These observations suggest that the small amount of protein associated with hyaluronic acid in normal joint fluid (Hamerman and Sandson, 1961; Schubert and Hamerman, 1964) may be derived from the synovial cells. 
Synovial Membrane in Traumatic Effusion.-This showed several striking differences from the normal with respect to the ultrastructural appearance and RNA histochemistry. Autoradiography with ${ }^{3} \mathbf{H}-$ leucine on the other hand showed a less definite distinction between the groups, possibly because of the high sensitivity of the method in detecting the $\beta$ emission from the incorporated amino acid. In all traumatic cases, however, the intensity of the autoradiographic image was dense, and this correlated with the results derived from RNA histochemistry. The number of cells staining positively for RNA increased with the increase in volume of fluid in the joint cavity (Fig. 1) and the intensity of their staining reaction also increased in a similar manner. These changes on analysis were statistically significant.

The ultrastructural studies agreed with these findings on protein synthetic capacity of synovial cells in patients with joint effusion. There was a reversal of the normal Type A:Type $B$ ratio, and large numbers of intermediate cells with a welldeveloped rough E.R. and Golgi system were identified. Although we have no direct evidence from our in vitro experiments to indicate a transfer of radioactive protein from the cells into fluid, all our findings are consistent with the view that some of the increased protein in traumatic joint effusion may be derived from the lining synovial cells.

\section{Summary}

Synovial biopsies from four normal subjects and eighteen patients with traumatic joint effusion were studied with histochemical, electron-microscopic, and autoradiographic techniques. With effusion RNA-positive synovial cells were more frequent and their numbers and the intensity of their staining reaction showed a significant increase with increase in the volume of synovial fluid. Electron micrographs of synovium from joints with effusion showed a marked increase in synovial cells containing rough endoplasmic reticulum and Palade granules. These features correlated with the heavy uptake of ${ }^{3} \mathrm{H}$-leucine by synovial cells after in vitro incubation and autoradiography. It is suggested that some of the excess protein found in synovial fluid in traumatic effusion may be contributed by the synovial cells.

This work was supported by a grant from the Arthritis and Rheumatism Council. We are indebted to Mr. A. Handyside for the statistical analysis and to Mr. F. W. Holdsworth and the other Staff members of the Orthopaedic Department of the Sheffield Royal Infirmary for help in collecting samples. We are grateful to Mr. T. L.
Platts, Mr. I. F. Coombe, Miss Ann Malone, and Mrs. Sandra Williams for their technical assistance.

REFERENCES
Barland, P., Novikoff, A. B., and Hamerman, D. (1962). J. Cell Biol., 14, 207.

Binette, J. P., and Schmid, K. (1965). Arthr. and Rheum., $8,14$.

Coulter, W. H. (1962). Ibid., 5, 70.

Curtiss, P. H. (1964). J. Bone Jt Surg., 46-A, 873.

Decker, B., McKenzie, B. F., McGuckin, W. F., and कs Slocumb, C. H. (1959). Arthr. and Rheum., 2, $\vec{\circ}$ 162.

Glauert, A. M. (1961). In "Techniques for Electron $\vec{\omega}$ Microscopy”, ed. D. Kay, pp. 179-181. Blackwell, Oxford.

Hamerman, D., and Sandson, J. (1961). Arthr. and i Rheum., 4, 420.

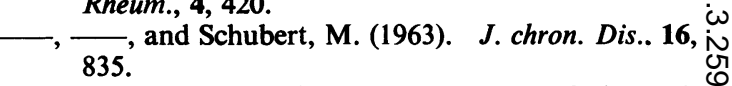
and Schubert, M. (1962). Amer. J. Med., 33, 555.

Hedberg, H., and Moritz, U. (1958). Proc. Soc. exp. Biol. (N.Y.), 98, 80.

Langer, E., and Huth, F. (1960). Z. Zellforsch., 51, 545.

Lever, J. D., and Ford, E. H. R. (1958). Anat. Rec., 132, 525.

McManus, J. F. A., and Mowry, R. W. (1960). "'Staining Methods: Histologic and Histochemical", p. 135. Hoeber, New York.

Palade, G. E. (1952). J. exp. Med., 95, 285.

(1961). In "Electronmicroscopy in Anatomy", ed. J. D. Boyd, F. R. Johnson and J. D. Lever, ֶ pp. 176-195. Arnold, London.

Parry, E. W., and Ghadially, F. N. (1965). Cancer, 18, $\stackrel{\varrho}{\rightrightarrows}$ 1026.

Peterson, M. R., and Leblond, C. P. (1964). Exp. Cell Res., 34, 420.

Reynolds, E. S. (1963). J. Cell Biol., 17, 208.

Ropes, M. W., and Bauer, W. (1953). "Synovial Fluid Changes in Joint Disease", pp. 78-82. Harvard University Press, Cambridge, Mass.

Shaw, N. E., and Martin, B. F. (1962). J. Anat., 96, 359.

Schubert, M., and Hamerman, D. (1964). Bull. rheum. Dis., 14, 345.

Yielding, K. L., Tomkins, G. M., and Bunim, J. J. (1957).을 Science, 125, 1300.

La membrane synoviale dans l'épanchement traumatique
L'ultrastructure et l'autoradiographie avec la leucine
tritiée
RésuMÉ

Des biopsies synoviales de quatre sujets normaux et de ${ }_{-}$ dix-huit malades atteints d'épanchement articulaire traumatique furent étudiées par des procédés histochimique, électron-microscopique et autoradiographique. En présence d'un épanchement les cellules synoviales? ARN-positives étaient plus fréquentes et leur nombre, 0 ainsi que leur réaction de coloration, accusaient une $\bar{O}$ augmentation significative correspondante à l'augmenta- $-\vec{\Phi}$ tion du volume du liquide synovial. Les micrographies? 
électroniques de la synoviale des articulations à l'épanchement accusaient une augmentation marquée des cellules synoviales contenant un réseau endoplasmique grossier et des granules de Palade. Ces caractéristiques correspondaient à une forte absorption de la ${ }^{3} \mathrm{H}$-leucine par les cellules synoviales après l'incubation in vitro et l'autoradiographie. On pense qu'une partie de la protéine excessive trouvée dans le liquide synovial des épanchements traumatiques peut dériver des cellules synoviales.

La membrana sinovial en el derrame traumático Ultrastructura y autoradiografía con ${ }^{3} \mathrm{H}$-leucina

\section{Sumario}

Biopsias sinoviales de cuatro sujetos normales y de dieciocho enfermos con derrame articular traumático fueron estudiadas con métodos histoquímico, electronmicroscópico y autoradiográfico. En presencia del derrame las células sinoviales ARN-positivas fueron más frecuentes y su número, así como la intensidad de su reacción de coloración, acusaron un aumento significativo con el aumento del volumen del derrame sinovial. Las micrografías electrónicas de la sinovia de las articulaciones con derrame revelaron un aumento acusado de las células sinoviales conteniendo un retículo endo- $\overline{\bar{\omega}}$ plásmico grosero y gránulos de Palade. Estos rasgos correspondieron a una fuerte absorpción de la ${ }^{3} \mathrm{H}-$ leucina por las células sinoviales después de la incubación in vitro y la autoradiografía. Se sugiere que una parte de la proteina excesiva encontrada en el líquido sinovial de los derrames traumáticos puede proceder de las células sinoviales. 